\title{
Migration and Identity Crisis in Benyamin's Goat Days
}

\author{
Surya Suresh Kumar \\ Guest Faculty \\ St. Teresa's College \\ Ernakulam, Kerala, India \\ suryakailasam30@gmail.com
}

\begin{abstract}
Migration is the movement of people from one place/country to another in search of better job opportunities or educational purposes or occurs due to political and social conflicts. This brings about a change in their social, cultural and psychological circumstances, which often makes them feel alienated in their lives. They experience a sense of disillusionment and loss of identity, which gradually leads them into psychological trauma where they start to question their identity. Benyamin's Goat Days portrays the life of Najeeb, a poor Malayali who in the hope of earning money decides to work in the Gulf. However, his journey of hope soon transforms to despair with the cruel treatment of his sponsor. He finds himself, alienated among the herd of goats and yearns to meet his family. His desolation pushes him into a psychological trauma where he starts to identify himself with the goats. This paper focuses on the concept of migration, alienation and identity crisis faced by Najeeb, the protagonist who represents the hopes and desires of every Malayali who yearn for a sumptuous future, which they believe will be offered in the Gulf. Moreover, the novel is set in the background of the Oil Era in the Gulf which gives every Malayali the dream of a secure future.
\end{abstract}


Keywords: Migration, Dehumanisation, Alienation, Identity Crisis, Psychological Trauma, Isolation, Migrant Labourers.

The advent of the Oil Era in the gulf in the 1960s and '70s resulted in the migration of large number of Indians to the Gulf. Labour migration, presently has become a global phenomenon which ensures economic benefits to the Gulf countries and also the migrant labourers and their countries. However, most of these labourers enter into the "kefala or sponsorship and guarantorship system" (Ahmad 10) which provides them with temporary labour. Thereby, they gain the status of "temporary migrant labourers" (Ahmad 10). The migrant labourers, mostly head from South Asia, Southeast Asia, Africa and Sri Lanka, to name a few. Andrew Gardener in his essay "Why Do They Keep Coming? Labour Migrants in the Gulf States" claims that "the flow of migrants to the Gulf is buoyed by disinformation and misinformation that inaccurately portrays the Gulf experience to potential migrants" (12). Manpower agencies based in the Gulf, in conjunction with the local sponsors of migrant labour, often collude in this systemic deception: men and women arrive in the Gulf to find themselves working in different positions and for lower wages than they were originally promised. While, it is impossible to pin this deception on any particular junction in this migration system, it is nonetheless true that from the perspective of the population of migrants part of the reason they keep coming to the Gulf is that they are working with imperfect information about the conditions of work and vulnerability they face in the sponsorship system. (Gardener 13)

In India too, there are considerable number of migrant labourers who are often tricked to give money in the name of completion of the visa procedures by fraudulent middlemen. They end up giving their savings in the hope of gaining a secure future. However, these labourers become a part of the shepherd community who are employed in herding the goats in the deserts of the Arab soil. They become victims of dehumanisation which results in the 
loss of their native identity. They, also face difficulty in maintaining contact with their family members and even the outer world. Till the end of the contract, the desert becomes their homeland and the goats become the only living creatures known to them.

Moreover, the Oil Era in the Gulf resulted in the migration of several Malayalis in search of better prospects to the Gulf. They usually work on a contract basis at the end of which they return to their homeland. Their poverty causes them to yearn for jobs in the Gulf. However, they become victims of fraudulent middlemen who dupe them to give them money for providing them with the jobs. However, in most of these cases they remain trapped in the deserts of the Middle-East countries where they become shepherds and end up being tortured by their sponsors.

The author Benyamin in one of his interviews with The Hindu said "Millions of Malayalis work in the Gulf. A sizeable number of them are manual labourers. Their wages are miserably low and living conditions are pathetic. I wanted to talk about the many who lead lives of suffering and pain. Many writers must have heard the story of Najeeb before. But it was my destiny to write the novel"

Goat Days portrays Najeeb as an individual who is caught between his life in Kerala and the masara. His life in the masara alters his daily routine which causes a psychological trauma in him. He experiences alienation from his own self, which marks the basis of his loss of identity. In addition to this, Najeeb's migration to the Gulf has also cost him his identity. Throughout the novel, he is portrayed as the character who suffers existential crisis.

I had not even brushed my teeth in the morning, nor followed any of the morning rituals. I hadn't taken a bath. Had it been at home, I wouldn't even drink coffee without first ducking into the river-even when it rained. But that day, for the first time, I violated all my hygiene rules. I had drunk milk without brushing my teeth. Hunger for one and half days forced me to ignore my habits. (Benyamin 68) 
Like every Malayali's aspiration for a better future, Najeeb also wishes for the same which forces him to labour in the deserts of the Gulf. Amartya Sen in his book The Identity and Violence: The Illusions of Destiny, describes identity crisis as "losing one's history and one's past identity in the complex world of the present" (18). Moreover, he also confronts the change in food patterns and clothing which also marks the basis for the same.

Throughout the novel, Najeeb becomes the victim of identity transformation. In the beginning, his job opportunity in Riyadh marks the first transformation from a Malayali to an Arab which he cherishes. But his entry to the masara brings a complete transformation where his identity is altered to a shepherd, goat, human being and so on. Thus, Najeeb gradually loses the trace of being a Keralite who consider life, merely as a source of existence.

Man, being a social animal needs the companion of fellow beings for his existence. However, Najeeb is stuck within the confines of the masara away from the outer world which is conveyed through "I lived on an alien planet inhabited by some goats, my arbab and me" (Benyamin 125). Here, he is exposed only to a herd of goats where he starts identifying himself with them. "I ate with salt...I slept in the masara with the goats. By then I had indeed become a goat" (150). Najeeb finds himself lost in the trauma associated with his alienation which indeed, shatters his dreams. He claims "I didn't have enough food, water, clothes, a proper place to sleep, wages, dream or aspirations. But I did have something precious leftmy life" (141).

The psychological trauma faced by Najeeb is explicit in his relationship with the goats. He addresses the goats with the name of his acquaintances which he considers as means to escape alienation. Also, he tends to a goat which suffers from labour pain which he relates to the birth of his son. He identifies the birth of the baby goat as the sign of Allah about his wife's delivery and the birth of their son Nabeel and addresses the goat by the name Nabeel (the name he had decided for his son). He caresses it and nurtures it as his child. 
Although he is beaten up by the arbab for attending the goat, he considers it as the responsibility of a father and therefore undertakes the same.

He was naughty from the beginning. It was his habit to fight with he-goats bigger than him. Some goats would accommodate his friskiness, but some would strike him with horns. How many times he came to me bleeding! Unseen by the arbab, I would take water from the tank and clean his wounds and apply on them the medicine the arbab had. Nabeel recognised and returned the special treatment I gave him. ( 111).

This clearly portrays the psychological trauma faced by Najeeb who satisfies his desire as a father by nurturing the goat as his son.

However, his life in the prison after his escape from the masara marks a reversal to his identity as a Malayali. "Each block was so long that one couldn't see the end of it. One block for each nationality- Arabs, Pakistanis, Sudanese, Ethiopians, Bangladeshis, Filipinos, Moroccans, Sri Lankans and then, finally, Indians. Most of the Indians were surely Malayalis" (11). "After noting two new arrivals, someone from a Malayali-looking cluster looked up to say, 'Don't worry, most of us here are Malayalis. Join any group you like,' and returned to the discussion". (14). Najeeb is thus, able to experience the sense of belonging and affection among the group of Malayalis where he once again is able to claim his identity.

Moreover, religion also serves as the factor of hope to Najeeb. He pacifies himself by relating his situation as the will of Allah. He believes in predestination and thus consider everything is Allah's will. This can be viewed as a means of escape that Najeeb uses to encounter the trauma that he faces due to the fear of losing his identity. He considers God as means to justify his existence and thereby, confront the events in his life.

Although Najeeb's life in the prison gave him a relief from the psychological trauma and also a sense of identity, he is continued to be haunted by the life in the masara. His identification with the goats bothers him in the prison too. He expresses his difficulty in 
having mutton served in the prison which is evident in his claim "When it was mutton, I wouldn't eat that meal" (18).

In the beginning, I would I realize that it was mutton in the biryani only after touching the food on the plate. I would then just shake it off my hand, get up and go away. Later, I began enquiring in advance. On the mutton days, I wouldn't even sit for meal; I would restrict myself to the tea and biscuits served after asar. It was the same at night. When khubus and meat were served in the meal between the maghreb and isha prayers, I would back off if there was mutton the plate. I would dip the khubus in water and eat. I had no difficulty in eating khubus without curry. That had been my diet for many years! (19).

In this process, Najeeb recalls his life in the masara and the food which includes khubus, water and fresh goat milk. In short, however, hard Najeeb tries to get rid of his dreadful past, the more it haunts him.

Goat Days also portrays the existence of hegemony through the lives of the arbab and Najeeb. Cultural hegemony is an important issue faced by the migrant labourers in the Gulf. Antonio Gramsci developed the idea of hegemony in his book Prison Notebooks where he defines it as the control and leadership of a group over another. According to Gramsci, cultural hegemony occurs when a group in the society assumes authority and thereby, controls the economic, political and social interests and decisions of another group. This shows the existence of subaltern groups in the society.

Through his novel, Benyamin portrays Najeeb as a subaltern who is subjected to the atrocities of his sponsor. The arbab in the novel assumes hegemony due to his Arabic identity. In spite of the same living conditions, the arbab experiences freedom, which his identity offers him. This shows the cultural hegemony that diminishes Najeeb's status as the "other". He becomes the subaltern in the Arabic land who is subjected to the hegemonic rule 
of his arbab and thereby, in this process of subjugation becomes a victim of psychological trauma due to the loss of his identity.

However, Najeeb enjoys his identity of being a Malayali, which he cherishes during his prison life. But he is instilled with the fear of losing his identity once again which is evident through his reaction to the identification parade which occurs periodically in the prison. "After standing there for a long time, the arbab tapped on my shoulder once. Then, as if he didn't recognize me, he moved on to next one. I don't know what made the arbab who had come to catch me change his heart" (250).

The identification parade was a horrific event for every prisoner as it is a mark of their slavery. Najeeb is terrified with the appearance of his sponsor as he is afraid of being trapped, once again in the desert with the goats. He also fears the loss of his identity which he has gained back. This shows the transition in Najeeb who once had cherished being a migrant labourer in the Gulf but, who is now adamant in holding back his identity as a Malayali. The life in the deserts of the Gulf have made him realise the importance of identity.

Najeeb's journey back to Kerala can be considered as his resurrection from his life in the desert of the Arabic land. His acceptance "Mine was a goat's life" (253) portrays his ability to fall in terms with the reality of being the "other" in the unknown land. His journey to Kerala is the journey of his self -realisation which he cherishes. Through the above lines, Najeeb tries to express the feeling of alienation that a foreign land offers its migrants where they are simply reduced to the status of the other. While, his happiness in returning to his homeland signifies the sense of belonging and identification of the self. Thus, in short Najeeb's story proves that one's homeland always gives him the sense of affection and belonging where he is able to flaunt his identity.

Our return flight was at night. The embassy officials distributed the boarding passes. Together, we were made to walk towards the plane. I could not help thinking how the 
sight was so similar to herding a flock of goats back into a masara! I was one of the goats. Mine was a goat's life. (253)

In the author's note, Benyamin narrates his experience with Najeeb and the story of his life which inspired him to write the novel.

How many millions of Malayalis live in the Gulf? How many millions have lived and returned to the homeland! But how many of them have really experienced the severity of the desert? I didn't sugar-coat Najeeb's story or fluff it up to please the reader. Even without that, Najeeb's story deserves to be read. This is not Najeeb's story, it is real life. A goat's life. (255)

Thus, Benyamin's novel Goat Days can be viewed as an example of Indian diasporic literature, which focuses on the miserable lives of the Gulf Malayalis. Through Najeeb, Benyamin portrays a tale of survival and the struggle of an individual who in the process of redefining his identity, ultimately ends up losing it. 


\section{Bibliography}

Ahmad Attiya. "Beyond Labour in the Gulf." Centre for International and Regional Studies, 25 May 2011, www.repository.library.georgetown.edu.in. Accessed 7 Mar. 2018.

Benyamin. Goat Days. Translated by Joseph Koyipally, Penguin Books, 2012.

Chalcraft, John. "Monarchy, migration and hegemony in the Arabian Peninsula."

Kuwait Programme on Development, Governance and Globalisation in the Gulf States, 26 Oct 2010. www.eprints.lse.ac.uk. Accessed on 7 Mar 2018.

Gardener, Andrew. "Why Do They Keep Coming? Labour Migrants in the Gulf States." Centre for International and Regional Studies, 25 May 2011, www.repository.library.georgetown.edu.in. Accessed 7 Mar. 2018.

Narnolia, Nitesh, Mousam. Migration and its Psychological Impacts: A Study of Benyamin's Novel Goat Days. Global Research Forum on Diaspora and Transnationalism, 3 Mar 2012. www.grfdt.org. Accessed on 2 March 2018.

Nivesh, Sudhaveni. "Indian Migration to Gulf Countries: Issues and Challenges" International Research Journal of Commerce Arts and Science”, vol.6, no.6, pp. 76-81, www.casirj.com. Accessed 7 Mar 2018.

Orellana, Carlos De. "Gramsci on Hegemony." Not Even Past, 26 May 2015, www.notevenpast.org. Accessed 7 Mar. 2018.

Sen, Amartya. The Identity and Violence: The Illusions of Destiny.Penguin Books, 2007. Varma, Shreekumar. "Life and times of a Goat". The Hindu, [Kochi], 06 Oct 2012, p. 11. "Aadu Jeevitham portrays bitter life of migrants in Gulf: Benyamin." The Hindu, 30 May 2012. 